\title{
Two Important Risk Factors in Imipenem Resistant Acinetobacter spp. Infection: Hemodialysis and Hypoalbuminemia
}

\author{
İmipenem Dirençli Acinetobacter spp. Enfeksiyonunda İki Önemli Risk Faktörü: Hemodiyaliz ve
} Hipoalbüminemi

\author{
Merve Sefa SAYAR ${ }^{1}$, Fatma Aybala Altay ${ }^{2}$, ID İran Şencan² \\ 1-TC SBÜ Van Eğitim ve Araştırma Hastanesi Enfeksiyon Hastalıkları ve Klinik Mikrobiyoloji 2-TC SBÜ Dışkapı Yıldırım Beyazıt \\ Eğitim ve Araştırma Hastanesi Enfeksiyon Hastalıkları ve Klinik Mikrobiyoloji
}

\begin{abstract}
Objectives: It is aimed to evaluated factors affecting the development of resistance to imipenem resistant Acinetobacter spp. infections with this study.

Materials and methods: This study was conducted retrospectively on outpatients treated in the main intensive units of the Diseases and Clinical Microbiology Department of Ylldrrm Bayezit Education and Research Hospital between January 1st, 2008 and December 31st, 2011. The data of the patients, infection control committee follow-up forms, laboratory data in the hospital follow-up system and epicrisis were used in the analysis.

Results: 248 patients were included in this study (mean age: 65.1 $17.8,60.9 \%$ males). $80.4 \%$ of the patients had a comorbid factor (diabetes mellitus, chronic obstructive pulmonary disease, congestive heart failure, malignancy, neurological disorder). Investigating the effects of other antimicrobials, strains with aminoglycoside resistance were statistically significant [p: 0.005]. Dialysis and albumin value $<3 \mathrm{~g} / \mathrm{dl}$ were found to be risk factors $[p<0.05]$. We also found that the rate of imipenem resistance increased by 3.8 fold and by 2.3 fold when albumin level was below 3 .

Conclusion: The factors of imipenem resistance were investigated in patients with Acinetobacter species in the intensive care unit and in those who developed the infection at the hospital, and early diagnosis of those at risk was found to have great importance in terms of prognosis and mortality. Besides central venous catheter, dialysis and the presence of hypoalbuminemia were found to affect the development of imipenem resistance.
\end{abstract}

ÖZET

Amaç: Bu çalı̧̧mada, imipenem dirençli Acinetobacter spp. enfeksiyonlarında direnç geliş̧imini etkileyen faktörlerin değerlendirilmesi amaçlanmıştır.

Gereç ve Yöntem: Çalışmamızda 1 Ocak 2008 ve 31 Aralk 2011 tarihleri arasında hastanemiz ana yoğun bakım ünitelerinde yatarak takip edilen hastalartn dosyaları restrospektif olarak incelenmiștir. Bu incelemede, Acinetobacter spp.'ne bağlı hastane enfeksiyonu gelișen hastaların bilgileri, enfeksiyon kontrol komitesi takip formlarl, hastane takip sistemindeki laboratuvar verileri ve epikriz bilgilerinden yararlanilmıştır.

Bulgular: Çalışmaya 248 hasta dahil edilmiștir. Hastaların yas ortalaması $65.1 \pm 17.8$ (n:248) ve \% 61 ' $i$ erkek olarak saptanmıștır. Hastaların \%80,4'ünde eşlik eden komorbid bir faktör (Diyabetes Mellitus, Kronik Obstruktif Akciğer Hastalı̆̆l, Konjestif Kalp Yetmezliği, Malignite, Nörolojik bozukluk) bulunmaktadır. İmipenem direncinin gelişiminde diğer antimikrobiyallerin etkisi incelendiğinde; aminoglikozid direncinin varlığının risk faktörü olduğu görülmüștür [p:0,005]. Diyalize giren ve albümin değeri $<3 \mathrm{~g} /$ dl olan hastaların imipenem direncinde bu faktörlerin birer risk faktörü olduğu bulgusuna ulaşılmıştır $[p<0,05]$. İmipenem direnci gelişimindeki risk faktörlerine yapılan çok değişkenli analizlerde diğer faktörler kontrol edildiğinde; diyalize girmiș olmanın imipenem direnci tahmini rölatif riskini $3.8 \mathrm{~kat}$ artırdığ ve albümin düzeyinin 3 'ün altında olmasinin ise imipenem direnci tahmini rölatif riskini 2.3 kat artırmakta olduğu ortaya konulmuştur.

Sonuç: Yoğun bakım ünitelerinde Acinetobacter spp. ile hastane enfeksiyonu gelişmiş hastalarda, imipenem direnci varlğı̆n etkileyen faktörlerin bilinmesinin ve imipenem direnci gelişsimi açısından riskli hastaların erken tanınmasının prognoz ve mortalite açısından büyük önem taşıdığı görü̈lmüş̧ür. Hastalardaki santral venöz kateter varlığı, öncesinde antibiyotik kullanımı gibi durumların varlığının yanı sıra; diyaliz uygulanmış olması ve hipoalbüminemi direnç gelişiminde etkili olan faktörler olarak tespit edilmiștir.
Key Words:

Acinetobacter

Antibiotic resistance,

Risk factors

Anahtar Kelimeler:

Acinetobacter,

Antibiyotik direnci,

Risk faktörleri

\section{GÍRIS}

Son 20 y1l içinde sağlık bakımı, enfeksiyon kontrol uygulamaları, antimikrobiyal kullanımı ve bakteriyel direnç paternlerinde değişiklikler görülmüştür; bu durum gram negatif mikroorganizmalara bağlı hastane ilişkili enfeksiyon sıklığını da etkilemektedir (1). Acinetobacter baumannii suşları yoğun bakımlarda salgınlara sebep olan; önemli bir nozokomiyal patojendir (2). Sıklıkla çoğul direnç gösteren bakteri; ventilatör ilișkili pnömoni, cilt-yumuşak doku enfeksiyonları, üriner sistem enfeksiyonları, kan

Correspondence: Merve Sefa SAYAR, TC. SBÜ. Van Eğitim ve Araştırma Hastanesi, Süphan Mahallesi Hava Yolu Kavşağı 1. Kilometre EDREMIT/VAN E-mail: drmervesefasayar@yahoo.com_Phone: +90(432) 4449965

Cite this article as: Sayar MS, Altay FA, Şencan İ. Two Important Risk Factors in Imipenem Resistant Acinetobacter spp. Infection: Hemodialysis and Hypoalbuminemia. Phnx Med J. 2020;2(1):25-34. 


\section{Sayar et al.}

dolaşımı enfeksiyonları gibi birçok tabloyla hastane ortamında klinisyenin karşısına çıkmaktadır (3). Aminoglikozidler, kinolonlar ve karbapenemlerin bulunduğu çoğu antimikrobiyale karşı gelişen yüksek direnç oranları, son yıllarda bu bakterinin etken olduğu enfeksiyonlarda ciddi anlamda tedavi sorunlarına yol açarak, olası Acinetobacter spp. enfeksiyonu tanısı ile takip edilen hastalarda, ampirik tedavi tercihlerini önemli ölçüde etkilemektedir (4). Acinetobacter spp. izole edilen hastaların özelliklerinden dolay1; kolonizasyonu enfeksiyondan ayırt etmek zordur (5). Epidemik A. baumannii enfeksiyonlarında yüksek "Acute Physiology Assessment and Chronic Health Evaluation (APACHE) II' skoru, prematürelik, cerrahi girişim, üriner ve santral venöz kateter, mekanik ventilasyon ve süresi, öncesinde antimikrobiyal kullanımı (karbapenem, florokinolon, 3.kuşak sefalosporin, aminoglikozid), kan ürünleri kullanımı, kontamine parenteral solüsyon kullanımı, enteral beslenme, hastanede yatış süresi, birimdeki yoğun iş yükü, birimde enfekte veya kolonize hasta yoğunluğunun fazla olması risk faktörleri olarak bilinmektedir (6). Çalışmamızda 2008-2011 yılları arasında hastanemiz yoğun bakım ünitelerinde Acinetobacter spp.'lerinin etken olduğu hastane kökenli enfeksiyonlar irdelenerek; Acinetobacter spp. enfeksiyonu gelişen hastalar retrospektif olarak belirlenmiştir. Acinetobacter spp. enfeksiyonlarında tedaviyi optimize etmek ve direnç gelişiminde etkili olan risk faktörlerini tanımlamak amacıyla; hastanemizde gelişen imipenem dirençli Acinetobacter spp. enfeksiyonlarındaki risk faktörleri çalışmamızda irdelenmiştir.

\section{MATERYAL VE YÖNTEM}

Acinetobacter spp.'e bağlı gelişen hastane enfeksiyonlarındaki imipenem direnci ve risk faktörlerini incelemeyi amaçladığımız bu çalışma, 1 Ocak 2008 ve 31 Aralık 2011 tarihleri arasında, 807 yataklı hastanemizin ana yoğun bakım ünitelerinde (anestezi, dahiliye, nöroloji, kalp-damar cerrahi ve cerrahi yoğun bakım) 48 saatten uzun süre yatarak takip edilen 18 yaş üstü hastalarda retrospektif olarak dizayn edilmiştir. Bu çalışmanın T.C. S.B.Ü. Dışkapı Yıldırım Beyazıt Eğitim ve Araştırma Hastanesi etik kurulu tarafindan onaylandı (Karar tarihi: 07.01.2019, Karar sayısı: 58/17). Çalışmaya dahil edilen hastaların bilgileri enfeksiyon kontrol komitesi takip formlar1, hastane takip sistemindeki laboratuvar verileri ve epikriz bilgilerinden yararlanılarak elde edilmiştir. Hastaların kültür üremeleri mikrobiyoloji ve enfeksiyon hastalıkları laboratuvarlarında çalışılmıştır. Kan kültürleri için Bactec 9120 (BectonDickinson, $\mathrm{ABD}$ ) ve Bact-Alert 3D (BioMerieux, Fransa) otomatize kan kültür sistemleri kullanılmış olup; diğer kültürler geleneksel yöntemlerle koyun kanlı agara ve ' 'eosine-metilen blue'، (EMB) agara ekim yapılmıştır. Antibiyotik duyarlılıkları için Müeller-Hinton agarda (Salubris, Türkiye) Kirby-Bauer disk difüzyon yöntemi uygulanmıştır. Antibiyotik duyarlılıklarını bildirirken; o yıla ait CLSI kriterleri gözetilmiştir. Antibiyotik duyarlılıkları gruplandırılırken orta duyarlı olan mikroorganizmalar dirençli olarak değerlendirilmiştir.

Hastane enfeksiyonu tanısında; CDC'nin 2008 ve 2011 yıllarında önerdiği hastane enfeksiyonları tanımları kullanıldı. Araştırmamızın yapıldığı tarihler arasında Acinetobacter spp.'ne etken olduğu hastane enfeksiyonlarının tanısı konularak; antibiyotik tedavisi uygulanan hastalar çalışmaya kabul edildi. Hastane enfeksiyonu tanısı enfeksiyon kontrol hemşireleri ve enfeksiyon hastalıkları uzmanları tarafindan konuldu. Her bir hastanın demografik özellikleri, komorbid hastalıkları, enfeksiyon gelişimini kolaylaştırabilecek invaziv girişimleri, üreyen mikroorganizma ve mikroorganizmanın duyarlılık profilleri kaydedildi. Üremelerin tamamında kolistin ve tigesiklin duyarlılığ test edilemedi. Çünkü çalışma başlangıcında kolistin ve tigesiklin Acinetobacter spp. enfeksiyonlarının tedavisinde yeni kullanıma girdi ve pratikte de direnç oranları düşük olduğu için antimikrobiyal duyarlılık testleri kullanılmamaktaydı. Çalışmaya dahil edilen Acinetobacter suşları imipenem direncine göre; imipenem duyarlı Acinetobacter spp. ve imipenem dirençli Acinetobacter spp. şeklinde iki gruba ayrılarak istatistiki analizler bu gruplar üzerinden yapıldı.

\section{İstatistikî Analizler}

Tanımlayıcı ve ileri analizler SPSS, Open Epi ve Excel programları kullanılarak yapılmıştır. Verilerin değerlendirilmesinde; sayısal ve yüzde dağılımları, olası risk faktörlerini değerlendirmek için \%95 Güven aralığ1, \%5 hata payı, tahmini rölatif risk (OR) hesaplamaları kullanılmıştır. Kategorik değişkenlerin değerlendirilmesinde ki-kare, Fisher kesin ki-kare testi, ortalamalar arası farkın değerlendirilmesinde ortalamalar arası farkın anlamlılık testi (normal dağılım gösteren verilerde: independent student t-testi ve normal dağılım göstermeyen verilerde: Mann Whitney U testi) kullanılmıştır. İstatistiksel anlamlılık düzeyi \%5 olarak kabul edilmiştir. Lojistik regresyon için model oluşturulmuş ve modele ilk analizlerde direnç gelişimi açısından riskli bulunan faktörler ve istatistiksel anlamlılık düzeyi \%20'nin altında olanlar dahil edilmiştir. Daha sonra bu faktörler "back ward wald” yöntemiyle elenerek en son model oluşturulmuştur.

\section{BULGULAR}

Hastanemiz yoğun bakım ünitelerinde 1 Ocak 2008 ve 31 Aralık 2011 tarihleri arasında toplam 297 hasta hastane kökenli Acinetobacter spp. enfeksiyonu tanıs1 almıştır. Acinetobacter spp. kolonizasyonu kabul edilen ve yalnızca enfekte yabancı cismin uzaklaştırılması dışında antimikrobiyal tedavi uygulanmayan beş hasta, ayrıca kültür tekrarında Acinetobacter spp. üremesi devam eden 44 hasta çalışma dişında bırakılmıştır. Antibiyoterapi uygulanan 248 hasta çalışma kapsamına alınmış olup; istatistiki analizler bu hastalar üzerinden yapılmıştır. Çalışma süresince 248 hastanın Acinetobacter spp.'ne bağlı hastane enfeksiyonu 
Tablo 1: Hastaların Tanımlayıcı Özellikleri

\begin{tabular}{|c|c|c|}
\hline \multirow[t]{2}{*}{ Özellikler } & \multicolumn{2}{|l|}{$(n=248)$} \\
\hline & $\mathbf{n}$ & $\%$ \\
\hline Yaş & & \\
\hline Ortalama $\pm S S$ & & \\
\hline Ortanca (Min-Max) & \multicolumn{2}{|c|}{$68(16-98)$} \\
\hline Cinsiyet (Erkek) & 151 & 60.9 \\
\hline Herhangi bir komorbidite varlığı & 185 & 80.4 \\
\hline $\mathbf{D M}^{\ddagger}$ varlığg & 66 & 29.2 \\
\hline KOAH $^{\ddagger}$ varlığı & 58 & 25.8 \\
\hline KKY $Y^{\ddagger}$ varlığg & 73 & 32.6 \\
\hline Malignite varlığı & 51 & 22.2 \\
\hline Nörolojik bozukluk varlığı & 88 & 38.1 \\
\hline Son 1 ayda hastanede yatış öyküsü & 50 & 21.9 \\
\hline Yakın zamanda cerrahi öyküsü & 115 & 48.5 \\
\hline \multicolumn{3}{|l|}{ İlk tanısı } \\
\hline Nörolojik bozukluk & 65 & 26.3 \\
\hline Travma & 51 & 20.6 \\
\hline Solunum & 52 & 21.1 \\
\hline Cerrahi & 17 & 6.9 \\
\hline Genel Durum Bozukluğu & 18 & 7.3 \\
\hline Diğer & 44 & 17.8 \\
\hline \multicolumn{3}{|c|}{ Hastanede yatış yapılan yoğun bakım servisi } \\
\hline Nöroloji & 38 & 15.3 \\
\hline Beyin Cerrahi & 43 & 17.3 \\
\hline Dahiliye & 46 & 18.5 \\
\hline Cerrahi & 33 & 13.3 \\
\hline Anestezi & 68 & 27.4 \\
\hline $\mathrm{KDC}^{¥}$ & 20 & 8.1 \\
\hline \multicolumn{3}{|l|}{ Yoğun Bakım Yatış Süresi (gün) } \\
\hline Ortalama \pm SS & \multicolumn{2}{|c|}{$65.7 \pm 65.1$} \\
\hline Ortanca (Min-Max) & \multicolumn{2}{|c|}{$40(5-356)$} \\
\hline TPN $¥$ kullanımı & 212 & 85.8 \\
\hline Arteriyel katater varlığı & 97 & 39.8 \\
\hline Periferik damar yolu açılması & 241 & 97.2 \\
\hline İdrar sondası varlığı & 232 & 97.5 \\
\hline \multicolumn{3}{|l|}{ İdrar sondası süresi (gün) } \\
\hline Ortalama \pm SS & \multicolumn{2}{|c|}{$63.9 \pm 62.9$} \\
\hline Ortanca (Min-Max) & \multicolumn{2}{|c|}{$40(2-297)$} \\
\hline Gastro/Kolostomi Varlığı & 67 & 27.2 \\
\hline \multicolumn{3}{|l|}{ Gastro/Kolostomi Süresi (gün) } \\
\hline Ortalama \pm SS & \multicolumn{2}{|c|}{$194.7 \pm 578.2$} \\
\hline Ortanca (Min-Max) & \multicolumn{2}{|c|}{$76(6-3650)$} \\
\hline \multicolumn{3}{|l|}{ Gastro/Kolostomi Süresi (gün)** } \\
\hline Ortalama \pm SS & \multicolumn{2}{|c|}{$87.0 \pm 68.5$} \\
\hline Ortanca (Min-Max) & \multicolumn{2}{|c|}{$74.5(6-281)$} \\
\hline
\end{tabular}




\section{Sayar et al.}

Tablo 1 (Devam): Hastaların Tanımlayıcı Özellikleri

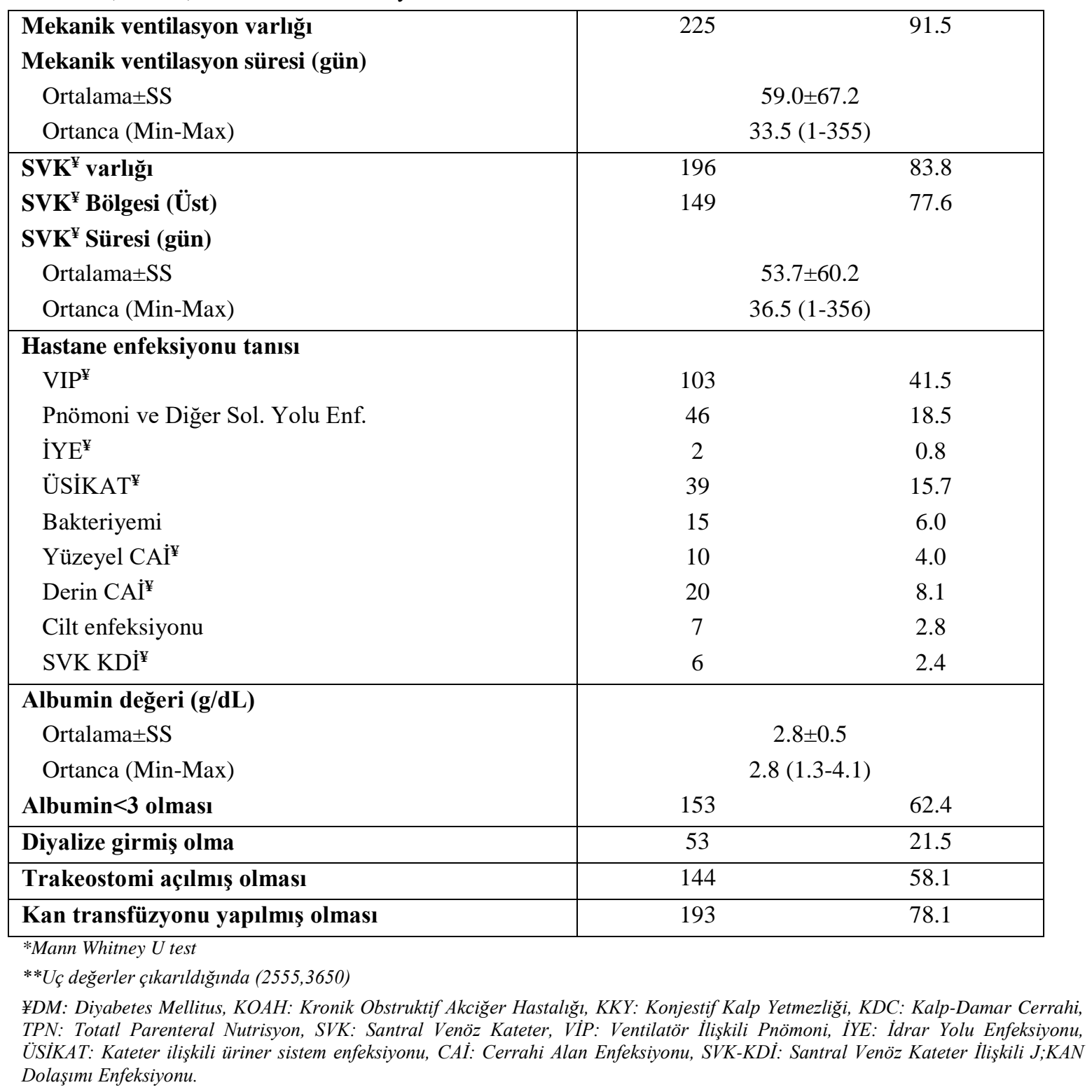

Tablo 2: Yoğun bakıma yatış öncesi antibiyotik kullanımı ve diğer antibiyotiklere direncin varlığının etkisi

\begin{tabular}{|c|c|c|c|c|c|c|}
\hline \multirow[t]{2}{*}{ Risk Faktörleri } & \multicolumn{2}{|c|}{$\begin{array}{l}\text { İmipenem Dirençli } \\
\text { Acinetobacter spp. } \\
(\mathrm{n}=209)\end{array}$} & \multicolumn{2}{|c|}{$\begin{array}{l}\text { İmipenem duyarlı } \\
\text { Acinetobacter spp. } \\
(\mathrm{n}=39)\end{array}$} & \multirow[t]{2}{*}{$\mathbf{p}$} & \multirow[t]{2}{*}{ OR (\%95 GA) } \\
\hline & & $\%$ & $\mathbf{n}$ & $\%$ & & \\
\hline Antibiyotik kullanım öyküsü & 120 & 60.3 & 16 & 42.1 & 0.038 & $2.1(1.1-4.2)$ \\
\hline \multicolumn{7}{|l|}{ Diğer antibiyotik direnci varlığı } \\
\hline Aminoglikozid & 191 & 91.4 & 29 & 74.4 & $0.005 *$ & 3.7 (1.6-8.7) \\
\hline 3./4. Kuşak Sefalosporin & 204 & 98.1 & 33 & 89.2 & $0.020 *$ & $6.2(1.5-25.9)$ \\
\hline Kinolon & 202 & 97.6 & 30 & 88.2 & $0.025 *$ & $5.4(1.4-21.2)$ \\
\hline Beta laktamaz inhibitörü & 203 & 99.5 & 35 & 92.1 & 0.013* & $17.4(1.8-172.1)$ \\
\hline Kolistin & - & - & - & - & - & - \\
\hline Tigesiklin & 41 & 29.9 & 4 & 21.1 & 0.424 & $1.6(0.5-5.1)$ \\
\hline
\end{tabular}

*Fischer kesin kikare testi 
tedavisi aldığı saptanmıştır. Hastaların yaş ortalaması $65.1 \pm 17.8$ (n:248) ve \%61 erkek cinsiyette idi. Hastaların \%80,4'ünde eşlik eden komorbid bir faktör (Diyabetes Mellitus, Kronik Obstruktif Akciğer Hastalığı, Konjestif Kalp Yetmezliği, Malignite, Nörolojik bozukluk) bulunmaktayd 1 (Tablo-1). Hastaların \%41,5'inin ventilatör ilişkili pnömoni (VİP) tanısı aldığı saptandı. Çalışmadaki hastaların \%15,7'sinde imipenem duyarlı Acinetobacter enfeksiyonu ve \%84,3'ünde imipenem dirençli Acinetobacter enfeksiyonu geliştiği saptand. İmipenem direncinin gelişiminde diğer antimikrobiyallerin etkisi incelendiğinde; aminoglikozid direncine sahip olmanın Acinetobacter spp. 'de imipenem direnci varlığı için anlamlı bir risk faktörü olduğu saptanmıştır (Tablo-2), (p:0,005). Hastalardan elde edilen Acinetobacter spp.'lerinin en sik derin trakeal aspirat örneklerinde (DTA) ürediği; ayrıca DTA örneklerindeki Acinetobacter spp.' lerin \%55 'inin imipenem dirençli ve \%59' unun imipenem duyarlı olduğu saptanmıştır. Üreme bölgeleri ile direnç arasındaki ilişki irdelendiğinde istatistiki olarak anlamlı bir sonuç elde edilememiştir $(p>0,05)$. Hastaların hastaneye yatış tanıları, invaziv işlemler, TPN uygulaması, kan transfüzyonu ve yatış süreleri ile imipenem direnci arasındaki ilişki değerlendirildiğinde bu faktörler ile imipenem direnci gelişimi arasında anlamlı bir sonuç elde edilememiştir (Tablo-3); ancak diyalize girmiş olmanın ve albümin değeri $<3 \mathrm{~g} / \mathrm{dl}$ olmasının imipenem direnci gelişiminde birer risk faktörü olduğu saptanmıştır (Tablo-3), $(\mathrm{p}<0,05)$. Hastaların aldıkları enfeksiyon tanıları ve kültür örneklerinin türü ile imipenem direnci gelişimi arasında istatistiki olarak anlamlı ilişki saptanmamıştır (p>0,05). İmipenem direnci gelişimindeki risk faktörlerini irdelemek amaçlı yapılan çok değişkenli analizlerde; diyalize girmiş olmanın imipenem direnci tahmini rölatif riskini 3.8 kat ve albümin düzeyinin 3 'ün altında olmasının imipenem direnci tahmini rölatif riskini 2.3 kat artırmakta olduğu saptanmıştır (Tablo4).

\section{TARTIŞMA}

A.baumannii non-fermenter, oksidaz negatif ve hareketsiz bir bakteridir, ayrıca hasta odalarının duvarları, anestezi ve ventilatör cihazları gibi cansız ortamlarda yaşayabilen; ciddi ve giderek artan sıklıkla kliniklerde görülen nozokomiyal bir patojen olup; insan florasında \%25 oranında kolonize olmaktadır (79). Koltuk altı, kasık bölgesi, parmak araları gibi nemli bölgelerin florasında bulunan Acinetobacter spp'ler; bu mikroorganizma ile enfekte hastalarda orofarinks, solunum sekresyonları ve ciltte de kolonize olmaktadır $(8,10,11)$. Acinetobacter spp. hastalarda ve çevrede kolonize olma yeteneğinden dolayı gram negatiflerin metisilin dirençli Staphylococcus aureus (MRSA)'u, üriner ve santral venöz kateterler gibi hastanede kullanılan aletleri kolonize edebilmesi nedeniyle de gram negatif bakterilerin koagülaz negatif stafilokoku olarak değerlendirilebilmektedir $(8,12)$. Vincent ve ark.'nın 2009 yılında yoğun bakım enfeksiyonlarını değerlendirdikleri çalışmalarında; 13.796 hastanın 7.087'sinin enfekte olduğunu, hastaların \%62'sinde gram negatif üreme bulunduğunu; ayrıca bu mikroorganizmaların \%8,8'inin Acinetobacter spp. olduğunu belirtmişlerdir (13). Meriç ve ark.'nın Türkiye'de yoğun bakım enfeksiyonlarını inceledikleri çalışmalarında \%26,8 ile Acinetobacter türleri en sık ikinci etken olarak karşımıza çıkmaktadır (14).

Acinetobacter türlerinin beta laktamları degrade eden enzimler, aminoglikozidleri modifiye eden enzimler, kinolonların bağlanma bölgelerindeki değişiklikler, çeşitli efluks mekanizmaları ve dış membran proteinlerindeki değişiklikler gibi çeşitli direnç mekanizmalarına sahip olması ile çevrede uzun süre yaşayabilmesi ve hemen hemen her türlü ortamda canlılığını sürdürebilme özellikleri birleşince tedavisi giderek zorlaşmaktadır (15). Çalışmamızda dikkat çektiğimiz Acinetobacter suşlarındaki karbapenem direncinin irdelendiği bir çalışmada; ABD'da 20022008 yılları arasında A.baumannii suşlarında çok ilaca direncin 2000 y1lında \%20,6 iken 2008 y1lında \%49,2'ye yükseldiği görülmüştür (16). Ülkemizde İskender ve ark.'nın 2000-2004 yılları arasında yaptıkları çalışmasında karbapenem (imipenemmeropenem) duyarlılığını \%84-86 saptamışlardır (17). Ülkemizde yoğun antibiyotik kullanımı ve uygunsuz tedavi seçimleri gibi faktörlerin etkisi ile direnç oranları yıllar itibarıyla artış göstermiş olup; Balcı ve ark. 2005-2007 arasındaki dönemi değerlendirdikleri çalışmalarında karbapenem (meropenem-imipenem) \%37-\%51, siprofloksasin \%18 ve amikasin \%34 duyarlı bulmuşlardır (18). Ülkemiz surveyans sistemi UHESA'nın 2017 verilerine göre ise; sağlık hizmeti ilişkili enfeksiyonlarda karbapenem dirençli A.baumannii sıklığı Türkiye genelinde genel ortalamanın \%70,46 ve sağlık bakanlığı eğitim ve araştırma hastanelerinde genel ortalamanın ise \% $\% 7,12$ olduğu bildirilmiştir (19). Çalışmamızda değerlendirdiğimiz Acinetobacter suşlarının imipenem direnci \%84,3 saptanmıştır. Hastanemiz bulunduğu bölge itibari ile yüksek riskli hastaların takip edildiği üçüncü basamak bir merkez olması nedeni ile çalışmamızda bulunan hastaların imipenem direncinin o yıllarda dahi yüksek olduğu görülmektedir.

Dirençli bakteri enfeksiyonları hastanede ve yoğun bakımda yatış süresinin uzamasına yol açmakta olup, ayrıca tanı amaçlı girişimler ve tedavi maliyetine bağlı olarak ciddi bir ekonomik yük oluşturur; uzamış hastane yatışı antibiyotik dirençli bakterilerle enfeksiyon gelişiminin de kolaylaşmasına sebep olmaktadır (20). İmipenem dirençli A.baumannii enfeksiyonları dirençli patojenler arasında tedavisi en zor patojenlerden biri olup; imipenem dirençli A.baumannii enfeksiyonu gelişen hastaların çoğu kritik hastalığa sahip, üriner kateter, santral venöz kateter ve endotrakeal tüp gibi invaziv işlemlere tabi tutulan hastalardır (21). Fukuta ve ark.'nın kanser hastalarında yaptıkları çalışmalarında Multi-drug resistance (MDR) A.baumannii kazanımının hematolojik malignitesi olma, diyaliz ihtiyacı, hastanın elektif cerrahi dışı 


\section{Sayar et al.}

Tablo 3: İmipenem dirençli ve İmipenem duyarlı Acinetobacter spp. için tek değişkenli risk faktörleri analizi

\begin{tabular}{|c|c|c|c|c|c|c|}
\hline Risk Faktörleri & \multicolumn{2}{|c|}{$\begin{array}{l}\text { İmipenem } \text { Dirençli } \\
\text { Acinetobacter spp. } \\
\left(\mathbf{n = 2 0 9 )} \begin{array}{c} \\
n\end{array} \quad \%\right.\end{array}$} & \multicolumn{2}{|c|}{$\begin{array}{l}\text { İmipenem } \quad \text { duyarlı } \\
\text { Acinetobacter spp. }(\mathrm{n}=39)\end{array}$} & $\mathbf{p}$ & OR (\%95 GA) \\
\hline Yaş & \multirow{3}{*}{\multicolumn{2}{|c|}{$\begin{array}{l}65.0 \pm 18.4 \\
68(16-98)\end{array}$}} & \multirow{3}{*}{\multicolumn{2}{|c|}{$\begin{array}{l}65.7 \pm 14.4 \\
69(29-88)\end{array}$}} & \multirow{3}{*}{0.787} & \\
\hline Ortalama \pm SS & & & & & & \\
\hline Ortanca (Min-Max) & & & & & & \\
\hline Cinsiyet (Erkek) & 130 & 62.2 & 21 & 53.8 & 0.326 & $1.4(0.7-2.8)$ \\
\hline Herhangi bir komorbidite varlığı & 154 & 79.8 & 31 & 83.8 & 0.575 & $0.8(0.3-2.0)$ \\
\hline DM varlığı & 56 & 29.6 & 10 & 27.0 & 0.750 & $1.1(0.5-2.5)$ \\
\hline KOAH varlığı & 49 & 26.1 & 9 & 24.3 & 0.825 & $1.1(0.5-2.5)$ \\
\hline KKY varlığı & 61 & 32.6 & 12 & 32.4 & 0.982 & $1.0(0.5-2.1)$ \\
\hline Malignite varlığı & 42 & 21.8 & 9 & 24.3 & 0.731 & $0.9(0.4-2.0)$ \\
\hline Nörolojik bozukluk varlığı & 72 & 37.1 & 16 & 43.2 & 0.482 & $0.8(0.4-1.6)$ \\
\hline Son 1 ayda hastanede yatış öyküsü & 43 & 22.5 & 7 & 18.9 & 0.629 & $1.3(0.5-3.0)$ \\
\hline Yakın zamanda cerrahi öyküsü & 102 & 51.3 & 13 & 34.2 & 0.054 & $2.0(1.0-4.2)$ \\
\hline \multicolumn{5}{|l|}{ İlk tanısı } & \multirow{7}{*}{0.853} & \\
\hline Nörolojik bozukluk & 55 & 26.4 & 10 & 25.6 & & - \\
\hline Travma & 42 & 20.2 & 9 & 23.1 & & \\
\hline Solunum & 43 & 20.7 & 9 & 23.1 & & \\
\hline Cerrahi & 16 & 7.7 & 1 & 2.6 & & \\
\hline Genel Durum Bozukluğu & 16 & 7.7 & 2 & 5.1 & & \\
\hline Diğer & 36 & 17.3 & 8 & 20.5 & & \\
\hline \multicolumn{7}{|l|}{$\begin{array}{l}\text { Hastanede yatış yapılan yoğun } \\
\text { bakım servisi }\end{array}$} \\
\hline Nöroloji & 30 & 14.4 & 8 & 20.5 & 0.150 & - \\
\hline Beyin Cerrahi & 39 & 18.7 & 4 & 10.3 & & \\
\hline Dahiliye & 37 & 17.7 & 9 & 23.1 & & \\
\hline Cerrahi & 31 & 14.8 & 2 & 5.1 & & \\
\hline Anestezi & 58 & 27.8 & 10 & 25.6 & & \\
\hline KDC & 14 & 6.7 & 6 & 15.4 & & \\
\hline \multicolumn{7}{|l|}{ Yoğun Bakım Yatış Süresi (gün) } \\
\hline Ortalama \pm SS & \multirow{2}{*}{\multicolumn{2}{|c|}{$\begin{array}{l}68.3 \pm 65.6 \\
44(5-356)\end{array}$}} & \multirow{2}{*}{\multicolumn{2}{|c|}{$\begin{array}{l}52.2 \pm 61.2 \\
38(8-356)\end{array}$}} & \multirow[t]{2}{*}{$0,104^{*}$} & \\
\hline Ortanca (Min-Max) & & & & & & \\
\hline TPN kullanımı & 179 & 86.1 & 33 & 84.6 & 0.813 & $1.1(0.4-2.9)$ \\
\hline Arteriyelkatater varlığı & 83 & 40.5 & 14 & 35.9 & 0.591 & $1.2(0.6-2.5)$ \\
\hline Periferik damar yolu açııması & 203 & 97.1 & 38 & 97.4 & $1.000 *$ & $0.9(0.1-7.6)$ \\
\hline $\begin{array}{l}\text { İdrar sondası varlığı } \\
\text { İdrar sondası süresi (gün) }\end{array}$ & 198 & 97.1 & 34 & 100.0 & 0.598* & - \\
\hline Ortalama \pm SS & \multirow{2}{*}{\multicolumn{2}{|c|}{$\begin{array}{l}66.0 \pm 64.4 \\
43(2-297)\end{array}$}} & \multirow{2}{*}{\multicolumn{2}{|c|}{$\begin{array}{l}51.6 \pm 52.6 \\
34(3-260)\end{array}$}} & \multirow[t]{2}{*}{$0,303^{*}$} & \\
\hline Ortanca (Min-Max) & & & & & & \\
\hline \multicolumn{6}{|l|}{ Gastro/Kolostomi Süresi (gün) } & $1.9(0.8-4.5)$ \\
\hline Ortalama \pm SS & \multicolumn{2}{|c|}{$134.5 \pm 355.0$} & \multicolumn{2}{|c|}{$696.2 \pm 1450.5$} & \multirow[t]{2}{*}{0.632} & \\
\hline Ortanca (Min-Max) & $76(6$ & & 107. & 50) & & \\
\hline Gastro/Kolostomi Süresi (gün)** & & & & & & \\
\hline Ortalama \pm SS & 85.1 & & & & $0.931 *$ & \\
\hline Ortanca (Min-Max) & 76( & & & & & \\
\hline $\begin{array}{l}\text { Mekanik ventilasyon varlığı } \\
\text { Mekanik ventilasyon süresi (gün) }\end{array}$ & 191 & 91.8 & 34 & 89.5 & $0.543^{*}$ & $1.3(0.4-4.2)$ \\
\hline Ortalama \pm SS & 61.1 & & & & $0,374^{*}$ & \\
\hline Ortanca (Min-Max) & 33.5 & & & & & \\
\hline YB-Üreme Süresi (gün) & & & & & & \\
\hline Ortalama \pm SS & 29.1 & & & & $0.103^{*}$ & - \\
\hline Ortanca (Min-Max) & 17( & & & & & \\
\hline
\end{tabular}


Tablo 3 (Devam): İmipenem dirençli ve İmipenem duyarlı Acinetobacter spp.için tek değişkenli risk faktörleri analizi

\begin{tabular}{|c|c|c|c|c|c|c|}
\hline \multicolumn{7}{|c|}{ Hastaneye Başvuru-YB Yatış Süresi (gün) } \\
\hline Ortalama \pm SS & \multicolumn{2}{|c|}{$3.2 \pm 4.3$} & \multicolumn{2}{|c|}{$4.3 \pm 6.3$} & $0.607 *$ & - \\
\hline Ortanca (Min-Max) & \multicolumn{2}{|c|}{$1(0-22$} & \multicolumn{2}{|c|}{$1(0-24)$} & & \\
\hline \multicolumn{7}{|c|}{ Hastaneye Başvuru-Üreme Süresi (gün) } \\
\hline Ortalama $\pm S S$ & \multicolumn{2}{|c|}{$32.2 \pm 31.3$} & \multicolumn{2}{|c|}{$26.4 \pm 25.1$} & $0.183 *$ & - \\
\hline Ortanca (Min-Max) & \multicolumn{2}{|c|}{$22(2-201)$} & \multicolumn{2}{|c|}{$19(4-116)$} & & \\
\hline SVK varlığı & 164 & 83.7 & 32 & 84.2 & 0.935 & $1.0(0.4-2.5)$ \\
\hline SVK Bölgesi (Üst) & 125 & 77.6 & 24 & 77.4 & 0.978 & $1.0(0.4-2.5)$ \\
\hline \multicolumn{7}{|l|}{ SVK Süresi (gün) } \\
\hline Ortalama \pm SS & \multicolumn{2}{|c|}{$55.0 \pm 59.2$} & \multicolumn{2}{|c|}{$46.5 \pm 66.4$} & $0,228 *$ & \\
\hline Ortanca (Min-Max) & \multicolumn{2}{|c|}{$38(1-356)$} & \multicolumn{2}{|c|}{$34(3-260)$} & & \\
\hline \multicolumn{7}{|l|}{ Hastane enfeksiyonu tanısı } \\
\hline VIP & 84 & 40.2 & 19 & 48.7 & - & - \\
\hline Pnömoni ve Diğer Sol. Yolu Enf. & 39 & 18.7 & 7 & 17.9 & & \\
\hline İYE & 1 & 0.5 & 1 & 2.6 & & \\
\hline ÜSIKAT & 34 & 16.3 & 5 & 12.8 & & \\
\hline Bakteriyemi & 11 & 5.3 & 4 & 10.3 & & \\
\hline Yüzeyel CAİ & 10 & 4.8 & - & - & & \\
\hline Derin CAİ & 17 & 8.1 & 3 & 7.7 & & \\
\hline Cilt enfeksiyonu & 7 & 3.3 & - & - & & \\
\hline SVK KDİ & 6 & 2.9 & - & - & & \\
\hline \multicolumn{7}{|l|}{ Albumin değeri (g/dL) } \\
\hline Ortalama \pm SS & \multicolumn{2}{|c|}{$3.1 \pm 0.4$} & \multicolumn{2}{|c|}{$2.8 \pm 0.5$} & 0.021 & \\
\hline Ortanca (Min-Max) & \multicolumn{2}{|c|}{$2.8(1.3-4.1)$} & \multicolumn{2}{|c|}{$3.0(2.2-4.1)$} & & \\
\hline Albumin $<3$ olması & 135 & 65.2 & 18 & 47.4 & 0.037 & $2.1(1.04-4.18)$ \\
\hline Diyalize girmiş olma & 50 & 24.0 & 3 & 7.7 & 0.022 & 3.8 (1.1-12.9) \\
\hline Trakeostomi açılmış olması & 125 & 59.8 & 19 & 48.7 & 0.198 & $1.6(0.8-3.1)$ \\
\hline Kan transfüzyonu yapılmış olması & 163 & 78.4 & 30 & 76.9 & 0.841 & $1.1(0.5-2.5)$ \\
\hline
\end{tabular}

Tablo 4: İmipenem dirençli Acinetobacter spp. için çok değişkenli risk faktörleri analizi

\begin{tabular}{|l|l|l|l|}
\hline Risk faktörleri & OR & \%95 GA & p \\
\hline Diyalize girmiş olma & $\mathbf{3 . 8}$ & $\mathbf{1 . 1 - 1 2 . 9}$ & $\mathbf{0 . 0 3 6}$ \\
\hline Albümin düzeyi $<3 g / d L$ & $\mathbf{2 . 3}$ & $\mathbf{1 . 1 - 4 . 7}$ & $\mathbf{0 . 0 2 2}$ \\
\hline Yakın zamanda cerrahi öyküsü & 1.9 & $0.9-4.0$ & 0.087 \\
\hline Son 1 ayda antibiyotik kullanma & 1.3 & $0.3-4.9$ & 0.720 \\
\hline
\end{tabular}

nedenlerle kabul edilmesi, başka sağlık merkezinden transfer olmuş olması, 1 haftadan uzun yoğun bakım ünitesinde kalma, mekanik ventilasyon, vasopressör kullanımı, tüp besleme, transfüzyon ve öncesinde antimikrobiyal kullanımını istatistiki olarak anlamlı risk faktörleri olarak saptanmıştır (22). Baran ve ark.'nın Türkiye'de yaptıkları çalışmalarında ise; hastaların \%53,7'si yoğun bakımlarda bulunup; hastaneye yatıştan ortalama 20.8 gün sonra imipenem dirençli A.baumannii üremesi olduğu görülmüştür (21). Çalışmada İmipenem dirençli A.baumannii enfeksiyonlarının ise servislerden ziyade yoğun bakım ünitelerinde olduğu görülmüştür $(\% 65,2)$. Yapılan çok değişkenli analizlerde A.baumannii üremesi olana dek hastanede yatışın süresi, öncesinde antibiyotik kullanımı ve yoğun bakım ünitesinde kalış diğer faktörlerden bağımsız bir şekilde imipenem direnci ile ilişkili bulunmuştur (21). Çalışmamızda yoğun bakım ünitesinde tedavi gören hastalarda Acinetobacter türlerinin etken olduğu hastane enfeksiyonlarında; hastanın yoğun bakım takibi süresince hemodiyalize girmiş olması ve albümin değerinin $<3 \mathrm{~g} / \mathrm{dL}$ olmasının imipenem direnci gelişiminde bir risk faktörü olduğu saptanmıştır $(\mathrm{p}<0,05)$.

Hipoalbüminemi geleneksel olarak karaciğer yetmezliği, malnutrisyon ya da protein kayılı enteropati gibi kronik durumlarla ilişkili olarak görülmektedir (23). Geriatrik hastalarda farklı parametreler nutrisyonel durumu değerlendirmede kullanılabilirken; serum albümin düzeyi sık kullanılan parametreler arasında yer almaktadır (10). Ancak kritik hastalarda yapılan çalışmaların görüşü; plazma albümin düzeyinin bu populasyonda bir nutrisyonal durum belirteçinden ziyade negatif akut faz patolojileri 
işaretçisi olmasından dolayı inflamatuar bir indikatör olduğu yönündedir $(23,24)$. Hipoalbüminemik hastalar mortalite ve morbiditesi olan kanser, kronik obstruktif akciğer hastalığı, diyabet, konjestif kalp yetmezliği ve miyokardiyal enfarkt gibi ana nedenlerle hastaneye kabul edilirler (25). Geriatrik yoğun bakım hastalarında albümin düzeyinin nutrisyon dışında enfeksiyon epizodları arasındaki ilişkisini inceleyen yeterli çalışma bulunmamaktadır (10). Septik hastalarda hipoalbüminemiyi analiz eden bir çalışmada APACHE II skoru ve hipoalbüminemi mortalite için bağımsız risk faktörü olarak tanımlanmıştır; serum albümin düzeyi $<2.9 \mathrm{~g} / \mathrm{dL}$ olan hastaların 28 günlük yaşam oranlarının daha düşük olduğu saptanmıştır (26). Yıldız ve ark.'nın çalışmalarında hipoalbüminemi (albümin<3.2 g/dL) olan hastalarda daha fazla mikrobiyolojik olarak kanıtlanmış enfeksiyon olduğunu saptamışlardır (10). Viasus ve ark.'nın toplum kökenli pnömoni ile hipoalbüminemi arasındaki ilişkiyi irdeledikleri çalışmalarında; hastaneye kabulünde albümin düzeyi düşük olan hastaların komplikasyon (bakteriyemi, septik şok, ampiyem, akut kardiyal durumlar yada nozokomiyal enfeksiyon gibi) riskinin önemli ölçüde daha fazla olduğunu saptamışlardır (25). Ciddi sepsis ve septik şok tabloları ile takip edilen toplum kökenli kan dolaşımı enfeksiyonlarının irdelendiği bir çalışmada hipoalbüminemi global mortalite ile ilişkili bir risk faktörü olarak saptanmıştır (Risk oranı, 0.33; 95\% CI, 0.15-0.76) (27). Sullivan ve ark.'1 vulvar kanserli hastalarda yaptıkları çalışmalarında; preoperatif hipoalbümineminin vulvar kanser hastalarında major postoperatif yara komplikasyonları (derin cerrahi alan enfeksiyonu, organ boşluk cerrahi alan enfeksiyonu,yara ayrılması veya greft/flep yetersizliği) ile ilişkili olduğunu saptamışlardır (28). Acinetobacter spp.'lerinde imipenem direnci gelişiminin etkileyen faktörleri irdelediğimiz çalışmamızda; çok değişkenli analizlerde; albümin düzeyinin $3 \mathrm{~g} / \mathrm{dL}$ 'ün altında olmasının imipenem direnci tahmini rölatif riskini 2.3 kat artırmakta olduğu saptanmıştır. Elde ettiğimiz veriler göz önüne alındığında; hipoalbümineminin enfeksiyon ve bakteriyel direnç gelişimine etkisinin açıklanmasında ileri çalışmalara ihtiyaç duyulmaktadır.

Hemodiyaliz gerektiren son dönem böbrek hastaları MDR organizmalarla sağlık ilişkili enfeksiyonların gelişimi ve kolonizasyonu açısından savunmasızdırlar; çünkü bu hasta grubu immunsupresyon, invaziv cihazlarla temas, diğer hastalarla ve sağlık çalışanları ile sık temas ve sık hospitalizasyon gibi multipl risklere sahiptirler (29). MRSA ve Vankomisin Dirençli Enterokok (VRE) kolonizasyonu ile ilgili diyaliz hastalarında birçok çalışma bulunurken; MDR gram negatiflerin kolonizasyonu ile ilgili yeterli çalışma yoktur (30). Örneğin Pop-Vicas ve ark.'nın hemodiyaliz hastalarındaki çalışmalarında; bu hasta grubunda MDR gram negatiflerin kolonizasyon oranını \%16 olarak saptamışlardır (31). Su ve ark.'nın MDR organizmalar ile böbrek fonksiyonları arasındaki ilişkiyi irdeledikleri çalışmalarında; spesifik patojenlere göre yaptıkları alt-grup analizlerinde glomerüler filtrasyon hızındaki azalma ile MRSA, Enterobacteriaceae spp., Enterococcus spp. ve Acinetobacter spp. de kaba MDR oranının arttığını saptamışlardır (32). Vasudevan ve ark.'nın kritik hastalarda MDR gram negatif basil enfeksiyonu gelişiminde; diyalize giren son dönem böbrek hastalığ olan hastaların yoğun bakım ünitesinde dirençli gram negatif bakterileri edinme ihtimalinin daha yüksek olduğunu saptamışlardır (33). Çalışmamızda yoğun bakım hastalarında Acinetobacter spp. enfeksiyonlarında imipenem direnci gelişiminde hastanın yoğun bakım takibinde diyalize girmiş olmasının imipenem direnci tahmini rölatif riskini 3.8 kat artırmakta olduğunu saptamış bulunuyoruz. $\mathrm{Bu}$ durum yoğun bakım takibinde hastaların diyalize giriyor olmasının dirençli enfeksiyonlara daha açık hale gelmesine sebep olduğu şeklinde yorumlanabilmektedir.

Acinetobacter türlerine karşı ilaç direnci yıllar içinde hızla gelişmiş ve günümüzde karbapenemler, betalaktamaz inhibitörleri (ampisilin-sulbaktam ve sefoperazon-sulbaktam) dahil birçok antibiyotik etkisiz hale gelmiştir; yan etkilerinden dolayı kullanımı kısıtlı olan kolistinin çok ilaca dirençli Acinetobacter türlerine etkili olduğu ortaya konulmuştur $(34,35)$. Antibiyotiklere direnç söz konusu olan MDR ya da pan-drug resistance (PDR) A.baumannii ile savaşta, kolistin / imipenem, kolistin/meropenem, kolistin / rifampisin, kolistin/tigesiklin, kolistin/sulbaktam, kolistin/teikoplanin ve imipenem/sulbaktam dahil kombinasyon tedavilerini kapsayan çalışmalar bulunmaktadır (36). Extreme drug resistance (XDR) suşların monoterapisindeki kısıtlılıkların ve PDR suşların ortaya çıkması dikkate alındığında; yeni direncin ortaya çıkmasını önlemek ve tedavi sonuçlarını iyileştirmek için potansiyel bir seçenek olarak kombinasyon tedavileri ileri sürülmüştür (37). Ancak özellikle gram negatif bakteriyel enfeksiyonlarda kombinasyon rejimlerinin in vivo direncin ortaya çıkmasını azaltabildiğini destekleyen çok az çalışma bulunmaktadır (37). Yunanistan da 93 XDR A.baumannii'ye bağlı ventilatör ilişkili pnömoninin irdelendiği çalışmada; kombinasyon tedavisi uygulanan grup ile monoterapi uygulanan grup arasında 28 günlük mortalite oranlarının benzer olduğu saptanmıştır (27.6\% vs. 30.9\%,p:0.751) (38). Hastane enfeksiyonlarında Acinetobacter spp. insidansını azaltmak ve dirençli suşlar ile enfeksiyon gelişimini önlenmesinde mevcut tedavi rejimleri ile ilgili sonuçlar göz önüne alındığında; hastaneyi ve hastaları yöneten personelin eğitimi ve rehberleri takip edip uyumu gerçekleştirmek iamacıyla ellerinden geleni en iyi şekilde yapması sağlanmalıdır. Ayrıca;

a) Hastalar ya da hasta ve medikal personel arasında çapraz enfeksiyondan kaçınmak için düzenli tespit ve bakteriyel kültür ile hastaneye yatışların iyileştirilmesi

b) Girişimsel işlemlerin ĕger mümkünse dĭger seçeneklerle değiştirilmesi; hastaların eksojen 
enfeksiyonlardan korunması için girişimsel işlemlerde doktor ve hemşirelerin dezenfeksiyon rejimlerine katı bir şekilde uymalarının sağlanması

c) Endojen mikroorganizmalar ile gelişebilecek firsatçı enfeksiyonları önleyebilmek için kritik hastalarda gerekli incelemelerin mümkün olduğu kadar erken yaplarak immun sistemlerinde yapılabilecek iyileştirmelerin sağlanması

d) Enfekte hastalar için, ilaca dirençli suşların oluşumunu geciktirmek ve bu suşların yayılmasını ve yaygınlığını kontrol etmek için klinik duruma göre rasyonel antibiyotik uygulaması sağlanmalıdır (8).

\section{Kisıtlılıklar}

Çalışmanın retrospektif olarak dizayn edilmiş olması ve çalışmanın yapıldığı dönemde henüz XDR Acinetobacter suşlarının saptanmamış olması çalışmanın kısıtlılıkları olarak ifade edilebilir. Yine de karbapenem direncini belirlemede iki önemli faktörü ortaya çıkarmış olması açısından çalışmanın faydalı olduğunu düşünüyoruz.

Sonuç olarak; çalışmamızda Acinetobacter spp. enfeksiyonlarında imipenem direncini etkileyen faktörler irdelenmiş olup; hipoalbüminemi ve diyalize girmiş olmanın Acinetobacter spp'ne bağlı hastane enfeksiyonlarında imipenem direnci gelişimi ile ilişkili olduğu saptanmıştır. Literatürde dirençli Acinetobacter spp. ile ilgili risk faktörü olarak hemodiyaliz ve hipoalbüminemiyi gösteren çok az sayıda çalışma mevcut olup bizim verilerimizin de katkı sağladığını düşünmekteyiz. Karbapenemlere karşı düzenli antimikrobiyal politikaları ve risk faktörleri bulunan hastalarda s1k1 enfeksiyon kontrol önlemlerinin uygulanmasının direnç gelişimi ve yayılımın önlenmesinde etkili olduğu bilinirken; hipoalbüminemisi olan ve diyalize giren hastalarda MDR gram negatif bakteri enfeksiyonu gelișimi hususunda daha dikkatli olunması gerekmekte olduğu görülmüştür.

ÇIKAR İLIŞKİsi

Tüm yazarlar çıkar çatışması ve finansal ilinti olmadığını beyan eder.

\section{KAYNAKLAR}

1) Gaynes R, Edwards JR. Overview of Nosocomial Infections Caused by Gram-Negative Bacilli. Clin Infect Dis. 2005;41(6):848-54

2) Lee SO, Kim NJ, Choi SH, Kim TH, Chung JW, Woo JH et al. Risk factors for acquisition of imipenem-resistant Acinetobacter baumannii: a case-control study. ANTIMICROBIAL AGENTS AND CHEMOTHERAPY. 2004;48 (1): $224-28$.

3) Bergogne-Berezın E, Towner KJ. Acinetobacter spp. As Nosocomial Pathogens: Microbiological, Clinical and Epidemiological Features. Clin Microbiol Rev. 1996;9(2):148-65.

4) Özdem B, Gürelik FÇ, Çelikbilek N, Balıkçı H, Açıkgöz ZC. Çeşitli Klinik Örneklerden 2007-2010 Yıllarında İzole Edilen Acinetobacter Türlerinin Antibiyotik Direnç Profilleri. Mikrobiyol Bul 2011; 45(3): 526-534.

5) Martin-Aspas A, Guerrero-Sanchez FM, Garcia-Colchero F, Rodriguez- Roca S, Antonio J, Gonzalez G. Differantial characteristics of Acinetobacter baumannii colonization and infection: risk factors, clinical picture and mortality. Infection and Drug Resistance 2018:11 861-872.

6) Akalın H. Yoğun Bakım Ünitesinde Dirençli Acinetobacter spp. İnfeksiyonlarına Yaklaşım. In: Arman D, Vahaboğlu H (ed). Dirençli Mikroorganizma İnfeksiyonlarına Yaklaşım. 1.Baskı. Ankara: Bilimsel Tıp Yayınevi. 2009:133-147.

7) Higgins PG, Dammhayn C, Hackel M, Seifert H. Global spread of carbapenem-resistant Acinetobacter baumannii. J Antimicrob Chemother. 2010,65(2):233-8.

8) Başustaoğlu A, Özyurt M. Nozokomiyal patojen olarak Acinetobacter'lerin mikrobiyolojik, klinik ve epidemiyolojik özellikleri, Hastane İnfeksiyon Derg 1998,2(2):88-93.

9) Wu HG, Liu WS, Zhu M, Li XX. Research and analysis of 74 blood stream infection cases of Acinetobacter baumannii and drug resistance. European Review for Medical and Pharmacological Sciences. 2018;22:1782-86.

10) Yildiz A, Yigit A, Benli AR. The impact of nutritional status and complete blood count parameters on clinical outcome in geriatric critically III patients. J Clin Med Res. 2018;10(7):588-592.

11) Romanelli RMC, Jesus LA, Clemente WT, Lima SSS, Rezende EM, Coutinho RL et al. Outbreak of resistant Acinetobacter baumannii Measures and proposal for prevention and control. The Brazilian Journal of Infectious Diseases. 2009;13(5):341-347.

12) Rello J, Diaz E. Acinetobacter baumannii: a threat for the ICU? Intensive Care Med. 2003;29(3):350-1.

13) Vincent JL, Rello J, Marshall J, Silva E, Anzueto A, Martin CD et al. International study of the prevalence and outcomes of infection in intensive care units. JAMA. 2009;302(21):2323-9.

14) Meric M, Willke A, Caglayan $C$, Toker K. Intensive Care Unit-Acquired Infections: Incidence, Risk Factors and Associated Mortality in a Turkish University Hospital. Jpn J Infect Dis.2005;58(5):297-302.

15) Fishbain J, Peleg AY. Treatment of Acinetobacter Infections. Clin Infect Dis. 2010;51(1):79-84.

16) Mera RM, Miller LA, Amrine-Madsen H, Sahm DF. Acinetobacter baumannii 2002-2008: Increase of Carbapenem-associated Multiclass resistance in the United States, Microb Drug Resist. 2010;16(3):209-15.

17) İskender S, Çaylan R, Sucu N, Aktoz Boz G, Köksal İ, Aydın K. Acinetobacter Suşlarının Antibiyotik Duyarlılıklarının Dört Yıllık Analizi. Hastane İnfeksiyonları Dergisi. 2006;10:161-65.

18) Balcı M, Bitirgen M, Kandemir B, Türk Arıbaş E, Erayman İ. Nozokomiyal Acinetobacter Baumannii Suşlarının Antibiyotik Duyarlılığı. ANKEM Derg. 2010;24(1):28-33.

19) Hekimoğlu CH, Batır E. Ulusal Sağlık Hizmeti İlişkili Enfeksiyonlar Sürveyans Ağı Etken Dağılımı ve Antibiyotik Direnç Raporu 2017. 


\section{Sayar et al.}

20) Kollef MH. In adequate Antimicrobial Treatment: An Important Determinant of Outcome for Hospitalized Patients. Clin Infect Dis. 2000;31:131-8. PMID: 11017862.

21) Baran G, Erbay A, Bodur H, Ongürü P, Akinci E, Balaban N et al. Risk factors for nosocomial imipenem-resistant Acinetobacter baumannii infections. Int J of Infect Dis. 2008;12(1):16-21.

22) Fukuta Y, Muder RR, Agha ME, Clarke LG, Wagener MM, Hensler AM et al. Risk factors for acquisition of multi drug-resistant Acinetobacter baumannii among cancer patients. American Journal of Infection Control.2013;41:1249-52.

23) Magnussen B, Gradel KO, Jensen TG, Kolmos HJ, Pedersen C, Vinholt PJ et al. Association between Hypoalbuminaemia and Mortality in Patients with Community-Acquired Bacteraemia Is Primarily Related to Acute Disorders. Plosone. 2016.11(9):1-14.

24) Soeters PB, Wolfe RR, Shenkin A. Hypoalbuminemia: Pathogenesis and Clinical Significance. JPEN J Parenter Enteral Nutr. 2019;43(2):181-193.

25) Viasus D, Garcia-Vidal C, Simonetti A, Manresa F, Dorca J, Gudiol F et al. Prognostic value of serum albumin levels in hospitalized adults with community-acquired pneumonia. Journal of Infection.2013;66:415-423.

26) Yin M, Si L, Qin W, Li C, Zhang J, Yang H, et al. Predictive Value of Serum Albumin Level for the Prognosis of Severe Sepsis Without Exogenous Human Albumin Administration: A Prospective Cohort Study. Journal of Intensive Care Medicine. 2016;33(12):687-694.

27) Artero A, Zaragoza R, Camarena JJ, Sancho S, Gonzalez R, Nogueira JM. Prognostic factors of mortality in patients with communityacquired blood stream infection with severe sepsis and septic shock. Journal of Critical Care.2010;25: 276-81. PMID:20149587.

28) Sullivan SA, Le LV, Liberty AL, Soper JT, Barber EL. Association between hypoalbuminemia and surgical site infection in vulvar cancers. Gynecologic Oncology.2016;142(3):435-9.

29) Barnes S, Permanente K, Concepcion D, Felizardo G, Moran J, Peters V et al. Guide to the Elimination of Infections in Hemodialysis, 2010. https://apic.org/Resource_/EliminationGuideForm/7966d850-0c5a-48ae-9090-a1da00bcf988/File/APIC-Hemodialysis.pdf. ErişimTarihi: 09.01.2018.

30) Calfee DP. Multidrug-Resistant Organisms With in the Dialysis Population: A Potentially Preventable Perfect Storm. Am J Kidney Dis. 2015;65(1):3-5.

31) Pop-Vicas A, Strom J, Stanley K, D’Agata EMC. Multidrug-Resistant Gram-Negative Bacteria among Patients Who Require Chronic Hemodialysis. Clin J Am Soc Nephrol. 2008; 3(3): 752-8.

32) Su G, Xu H, Riggi E, He Z, Lu L, Lindholm B et al. Association of Kidney Function with Infections by Multidrug-Resistant Organisms: An Electronic Medical Record Analysis. SCIENTIFIC REPORTS. 2018;8(1):13372.

33) Vasudevan A, Mukhopadhyay A,Li J, Yuen EG, Tambyah A. A prediction tool for nosocomial multi-drug resistant gram-negative bacilli infections in critically ill patients-prospective observational study. BMC Infectious Diseases 2014, 14:615.

34) Seyman D, Cengiz M, Özen N, Turhan Ö, Ramazanoğlu A, Yalçın AN. Çok ilaca Dirençli Acinetobacter infeksiyonlarında Kolistin Deneyimi. Hastane İnfeksiyonları Dergisi. 2010;14(3):367-72.

35) Xia J, Zhang D, Xu Y, Gong M, Zhou Y, Fang X. A retrospective analysis of carbapenem-resistant Acinetobacter baumannii-mediated nosocomial pneumonia and the in vitro therapeutic benefit of cefoperazone/sulbactam. Int J Infect Dis. 2014; Jun;23C:90-3. PMID:24726664.

36) Lee CR, Lee JH, Park M, Park KS, Bae K, Kim YB et al. Biology of Acinetobacter baumannii: Pathogenesis, Antibiotic Resistance Mechanisms, and Prospective Treatment options. Front Cell Infect Microbiol. 2017;7(55):1-35.

37) Wong D, Nielsen TB, Bonomo RA, Pantapalangkoor P, Luna B, Spellberg B. Clinical and Pathophysiological overwiev of Acinetobacter infections: a century of challenges. Clinical Microbiology Reviews. 2017;30 (1): 409-447.

38) Tsioutis C, Kritsotakis EI, Karageorgos SA, Stratakou S, Psarologakis C, Kokkini S et al. Clinical epidemiology, treatment and prognostic factors of extensively drug-resistant Acinetobacter baumannii ventilator -associated pneumonia in critically ill patients. International Journal of Antimicrobial Agents.2016;48(5):492-7. 